\author{
Mateusz DŁUGOSZ \\ Studenckie Koło Naukowe Geografów „Human Geography”, Uniwersytet Wrocławski \\ e-mail: mateuszdlugosz7@gmail.com
}

\title{
DEPOPULACJA AGLOMERACJI WAŁBRZYSKIEJ
}

\begin{abstract}
Abstrakt: Po przemianach ustrojowych Polski w latach 90. XX w., w aglomeracji wałbrzyskiej nastąpił kryzys lokalnej gospodarki, opartej dotąd głównie na górnictwie węgla kamiennego, który przyczynił się do ubytku ludności. Depopulacja ta zapoczątkowana w 1994 r., zachodzi obecnie w głównej mierze wskutek ubytku naturalnego i ujemnego salda migracji. Z analizowanego obszaru wyjeżdżają głównie ludzie młodzi, powodując zwiększenie udziału osób starszych w strukturze populacji i prowadząc do pogłębiania się procesu starzenia się ludności.

Słowa kluczowe: depopulacja, kurczenie się miast, starzenie demograficzne, aglomeracja wałbrzyska.
\end{abstract}

\section{THE DEPOPULATION OF WALBRZYCH AGGLOMERATION}

\begin{abstract}
Political transformations of Poland since 1990 resulted in the economic crisis of the Walbrzych agglomeration, which previous economic profile, was based on black coal mining - and the considerable loss of population number. In 1994 the depopulation was initiated and actually is caused both by negative values of birth rate and migration balance. Young people mainly emigrate from the analysed area, therefore, the percentage of older people in the age structure of population is increasing deepening the demographic ageing process.

Keywords: depopulation, shrinkage of cities, Walbrzych agglomeration, ageing of the population.
\end{abstract}

\section{WPROWADZENIE}

Zjawisko depopulacji zachodzi współcześnie w wielu ośrodkach miejskich na całym świecie. Miasta wyludniają się powodując nie tylko przemiany w strukturach demograficznych określonych obszarów, lecz przyczyniając się do zmian zachodzących na wielu płaszczyznach, m.in.: ekonomicznej, społecznej i planistycznej. Coraz częściej mówi się więc, nie tylko o depopulacji, ale nawet o kurczeniu się miast, ponieważ śladem ubytku ludności na określonych terenach pojawiają się problemy innej natury (por. Zborowski i in. 2012, Kantor-Pietraga i in. 2012).

Do niekorzystnych zmian ludnościowych dochodzi przede wszystkim na skutek występowania procesów o różnej genezie (Kantor-Pietraga 2014). Jedne to czynniki o genezie społecznej, zachodzące wewnątrz określonego społeczeństwa. Wśród nich wyróżnia się przede wszystkim ubytek naturalny, związany głównie z niskim współczynnikiem urodzeń $\mathrm{w}$ analizowanym miejscu. Prawdopodobnie ma to miejsce na skutek przemian społecznych, które określa teoria drugiego przejścia demograficznego. Kolejną przyczyną jest odpływ migracyjny będący efektem niekorzystnej sytuacji ekonomicznej. Wskazuje się, że migracje odgry- wają większą rolę w tym ubytku, niż inne czynniki społecznej natury (Parysek 2005).

Jako przyczyny depopulacji wskazuje się również zjawiska o naturze ekonomicznej. Wśród nich wymienia się przede wszystkim zmiany zachodzące $\mathrm{w}$ wyni$\mathrm{ku}$ transformacji funkcjonalnej, bowiem zmienia się baza ekonomiczna określonego obszaru. Przemiany zachodzące w Polsce na początku lat 90 . XX w. doprowadziły przede wszystkim do regresu bazy ekonomicznej ważnych wcześniej ośrodków przemysłowych. Najczęściej skutkiem tych przemian był upadek zakładów przemysłowych na terenie wielu miast, w efekcie czego pojawiło się tam bezrobocie przyczyniające się następnie do odpływu migracyjnego. Inną przyczyną depopulacji są zmiany thumaczone teorią mobilności przestrzennej ludności. Nawiązują do tego dwa etapy urbanizacji według Klaassena i Paelincka: suburbanizacja i dezurbanizacja, które zakładają ubytek ludności w centrach miast i przemieszczanie się jej do stref podmiejskich (por. Maik 1992).

Niniejsze opracowanie stanowi analizę zjawiska depopulacji i jej skutków demograficznych na obszarze aglomeracji wałbrzyskiej złożonej z gmin powiatu wał- 
brzyskiego oraz gminy miejskiej Świebodzice. Pojęcie aglomeracji, rozumianej jako zespół miast leżących blisko siebie i powiązanych funkcjonalnie (por. Szymańska 2009), zostało tu rozszerzone do terenów gmin położonych wokół miasta głównego - Wałbrzycha. W artykule dokonano analizy depopulacji dla Wałbrzycha i jego strefy podmiejskiej, którą stanowi pierścień gmin wokół tego miasta (zob. rys. 5).

\section{UWARUNKOWANIA PROCESU DEPOPULACJI}

Zmiany demograficzne w aglomeracji wałbrzyskiej związane są przede wszystkim z regresem jej bazy ekonomicznej wywołanym kryzysem lokalnej gospodarki. W 1989 r. w gospodarce polskiej została zapoczątkowana wielka transformacja funkcjonalna. Przemiany te dotknęły różnych rodzajów działalności gospodarczej, jednak szczególnie przemysłu ciężkiego, który do tego czasu był w znacznej mierze dofinansowywany ze środków publicznych. Przejście od gospodarki centralnie sterowanej do rynkowej spowodowało, że zakłady przemysłowe musiały się zmierzyć z konkurencją wolnorynkową. Zmiany te w sposób szczególny dotknęły Wałbrzycha i jego aglomeracji, ponieważ ta część Sudetów była zdominowana przez funkcje przemysłowe (Ciok i in. 2006). Węgiel kamienny wydobywany był w Dolnośląskim Zagłębiu Węglowym nieprzerwanie od XIX w. do lat 90. XX w. (Jaroszewska 2014). Na przełomie lat 80. i 90. XX w., wskutek wspomnianej transformacji funkcjonalnej, doszło do likwidacji wszystkich kopalń węgla kamiennego na obszarze tego zagłębia i zamknięcia wielu innych zakładów przemysłowych oraz przekształcenia gospodarki $\mathrm{w}$ regionie (Wójcik 2011). W efekcie restrukturyzacji wałbrzyskiego przemysłu doszło do głębokich przemian społecznych, gospodarczych i przestrzennych (Dołzbłasz, Mucha 2015). W regionie pojawiło się bezrobocie, które wcześniej było tu minimalne. Szczególnie dotkniętą przez transformację ustrojową grupą zawodową byli górnicy - wyspecjalizowani w jednym rodzaju działalności, nie mogli znaleźć pracy w innych działach przemysłu (Kosmaty 2011). Omawiana restrukturyzacja dotknęła również inne gałęzie przemysłu na terenie aglomeracji wałbrzyskiej, jak np. przemysł odzieżowy (Zakłady Przemysłu Odzieżowego „Rafio” w Świebodzicach i Wałbrzychu) i włókienniczy (Zakłady Przemysłu Lniarskiego „Silena” w Świebodzicach i Zakłady Przemystu Lniarskiego „Walim” w Walimiu).
Do odpływu ludności z omawianej aglomeracji przypuszczalnie mogła również przyczynić się utrata statusu ośrodka wojewódzkiego przez Wałbrzych, w wyniku reformy administracyjnej z 1999 r.; stolicą nowego województwa dolnośląskiego stał się Wrocław. Wałbrzych tym samym stracił swoją pozycję w hierarchicznym układzie miast jako ośrodek na prawach powiatu i siedziba powiatu wałbrzyskiego (w latach 2003-2013 nie był nawet miastem wydzielonym z powiatu - por. Kantor-Pietraga 2014). Utrata statusu miasta wojewódzkiego, wiążącego się z przeniesieniem siedziby władz województwa, przyczyniła się do zwiększenia odpływu migracyjnego (Szmytkie 2016).

\section{PROCESY DEPOPULACJI W AGLOMERACJI WAŁBRZYSKIEJ}

Upadek wielu gałęzi przemysłu w aglomeracji wałbrzyskiej spowodował pojawienie się na tym terenie stagnacji gospodarczej (Wójcik 2011), a taka sytuacja ekonomiczna wpływała na zachowanie społeczeństwa. Widocznym ich efektem były zachodzące tu przemiany demograficzne. Zjawiska zaistniałe wewnątrz społeczeństwa omawianej aglomeracji (w skrócie społeczne) są zarówno przyczyną, jak i skutkiem tej depopulacji.

Pierwszym czynnikiem prowadzącym do depopulacji jest ubytek naturalny ludności w liczbach bezwzględnych (rys. 1) oraz w przeliczeniu na 1000 mieszkańców (rys. 2). Niska ich wartość jest wynikiem trendów obecnych w społeczeństwie w ujęciu globalnym, związanych przede wszystkim ze zmianami cywilizacyjnymi, o których jest mowa w teorii drugiego przejścia demograficznego. Zakłada ona spadek rozrodczości wskutek zmian cywilizacyjnych i postępującej zmiany struktury rodziny (Holzer 2003). W ujęciu lokalnym zależy jednak od sytuacji społeczeństwa. Na całym analizowanym obszarze zachodzi ubytek naturalny, jednak gorzej jest w samym Wałbrzychu, niż w jego strefie podmiejskiej. Ma to związek przede wszystkim ze zmniejszającą się liczbą osób w wieku produkcyjnym oraz liczbą osób wkraczających w wiek rozrodczy, których jest za mało, aby mogło dojść do zastępowalności pokoleń przy niskim obecnie współczynniku dzietności.

O tempie wzrostu liczby ludności na danym obszarze informuje wspótczynnik przyrostu naturalnego, czyli różnica w liczbie urodzeń i zgonów odniesiona do ogółu populacji - na 1000 mieszkańców (\%o) (Holzer 
2003). W całej aglomeracji współczynnik ten ma wartości ujemne. Warto zauważyć, że w Wałbrzychu w okresie 1994-2015 r. wskaźnik ten jest znacznie mniejszy niż w strefie podmiejskiej, a na obszarze całej aglomeracji podlegał licznym fluktuacjom wynikającym chociażby ze zmieniającej się liczby urodzeń, ale także zmniejszającej się liczby ludności. Na tej podstawie można stwierdzić, że tempo depopulacji aglomeracji wałbrzyskiej jest silniejsze w przypadku samego Wałbrzycha, niż jego strefy podmiejskiej. Ujemna wartość współczynnika przyrostu naturalnego oznacza, że liczba urodzeń nie rekompensuje liczby zgonów, w efekcie czego na danym obszarze ubywa ludności. Wartość ubytku naturalnego, będącego przyczyną depopulacji, łącznie wynosiła 15682 osób w latach 1994-2015.

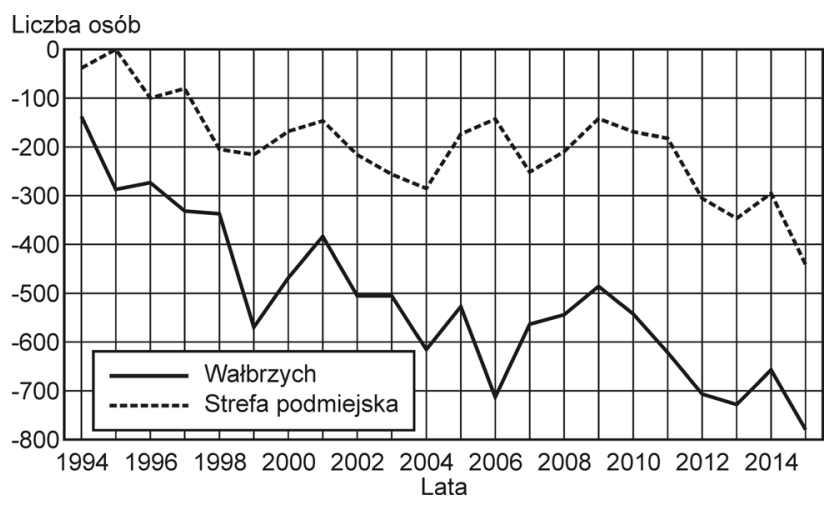

Rys. 1. Ubytek naturalny w aglomeracji wałbrzyskiej w latach 1994-2015

Źródło rys. 1-9: opracowanie własne na podstawie Banku Danych Lokalnych

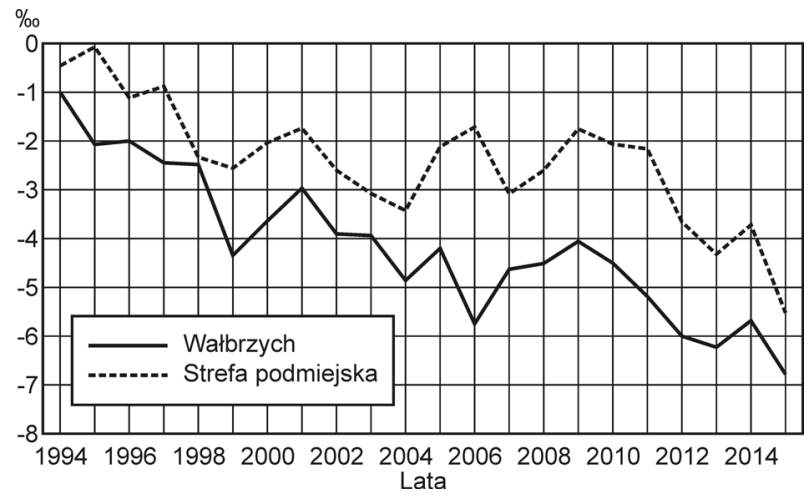

Rys. 2. Współczynnik ubytku naturalnego w aglomeracji wałbrzyskiej w latach 1994-2015

Drugim czynnikiem mającym wpływ na depopulację w ujęciu społecznym jest odpływ migracyjny wyrażany przez saldo migracji lub jego współczynnik (rys. 3). Wskaźnik ten stanowi wartość różnicy między napływem a odpływem z określonego obszaru przeli- czona na 1000 mieszkańców - w \%o. Na skutek pogarszającej się sytuacji gospodarczej, ludzie podejmują decyzję o migracji, nie widząc perspektyw dalszego rozwoju (Holzer 2003). Takie procesy miały właśnie miejsce w omawianej aglomeracji, gdzie stagnacja gospodarcza, zaobserwowana po upadku wielu zakładów przemysłowych, powodowała odpływ migracyjny (Wójcik 2011).

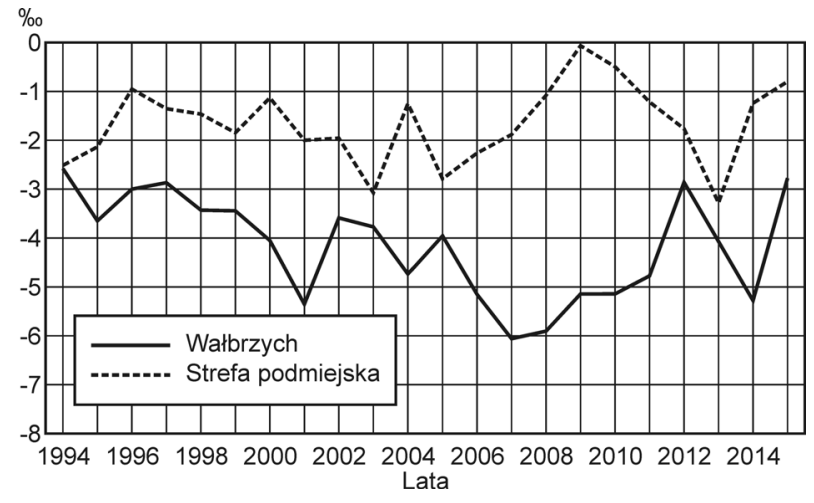

Rys. 3. Współczynnik salda migracji ludności w aglomeracji wałbrzyskiej w latach 1994-2015

W sposób szczególny na kurczenie się aglomeracji wałbrzyskiej wpływa migracja ludzi młodych, którzy - wyjeżdżając z Wałbrzycha na studia - po zakończonej edukacji nie wracają do miasta, gdyż nie widzą tam dla siebie perspektyw (Kosmaty 2011), i podobnie jest w gminach ościennych. Najczęstszym kierunkiem odpływu mieszkańców Wałbrzycha jest jego strefa podmiejska, co można wiązać z procesami suburbanizacji. Warto zwrócić uwagę, że jednym z miast, do którego udają się wałbrzyszanie jest pobliska Świdnica stanowiąca dla Wałbrzycha ważną konkurencję. Nie bez znaczenia dla odpływu migracyjnego jest też silne przyciąganie oddalonego o $60 \mathrm{~km}$ Wrocławia, który stanowi jedno z głównych miejsc emigracji mieszkańców Wałbrzycha udających się tam w celach zarobkowych, ale też edukacyjnych (Szmytkie 2016). Odpływ ten jest charakterystyczny dla Wałbrzycha i jego strefy podmiejskiej, z której gmin jest on jednak mniejszy. Wyższa wartość współczynnika salda migracji w strefie podmiejskiej może być poniekąd rekompensowana poprzez suburbanizację $\mathrm{i}$ związany $\mathrm{z}$ nią wzrost liczby ludności. Świadczyć o tym może przebieg łamanych - w pewnych okresach (por. rys. 3), gdzie dla Wałbrzycha i strefy podmiejskiej są one w pewnym stopniu własnym odbiciem lustrzanym. Suburbanizacja jednak nie jest właściwą interpretacją tej sytuacji migracyjnej, ponieważ wartość współczynnika salda migracji dla strefy podmiejskiej jest również 
ujemna, czyli liczba osób przyjeżdżających tam nie rekompensuje odpływu mieszkańców. Oznacza to, że na obszarze aglomeracji wałbrzyskiej dochodzi do depopulacji bezwzględnej, choć redystrybucja przestrzenna ludności wskutek suburbanizacji zmniejsza nieco skalę odpływu migracyjnego, wynoszącego w okresie 1994 -2015 r. łącznie 14509 osób.

\section{SKUTKI DEPOPULACJI AGLOMERACJI WAŁBRZYSKIEJ}

Liczba ludności w aglomeracji wałbrzyskiej od 21 lat nieprzerwanie spada, o czym dobitnie informuje rys. 4. W roku 1994 liczba ludności zamieszkującej ten obszar osiągnęła maksimum. Wałbrzych zamieszkiwały wówczas 140022 osoby i była to maksymalna liczba ludności w historii tego miasta, w którego strefie podmiejskiej mieszkało wtedy 87985 osób. W tamtym roku rozpoczął się spadek liczby ludności, który w ciągu następnych lat wyniósł dla całej aglomeracji 32,5 tys. osób, w tym 24,6 tys. (76\%) stanowiła depopulacja samego Wałbrzycha. W latach 1994-2015 liczba ludności tego miasta spadła o 21,3\% - średnio po 1170 osób/ rok. Warto zwrócić uwagę, że większą depopulację obserwowano w okresie 1994-2004 r., gdyż wówczas Wałbrzych stracił 13557 osób, czyli średnio 1232,5 osoby/rok. Później (lata 2005-2015) tempo depopulacji zmniejszyło się nieco - do 1001,5 osób/rok i Wałbrzych wyludnił się o kolejne 11012 osób. W strefie podmiejskiej ubytek ludności był mniej intensywny. W latach 1994-2015 liczba ludności w gminach wokół Wałbrzycha spadła o 7900 osób, czyli o 9,9\%, a więc zmniejszała się średnio o 376,6 osób rocznie.

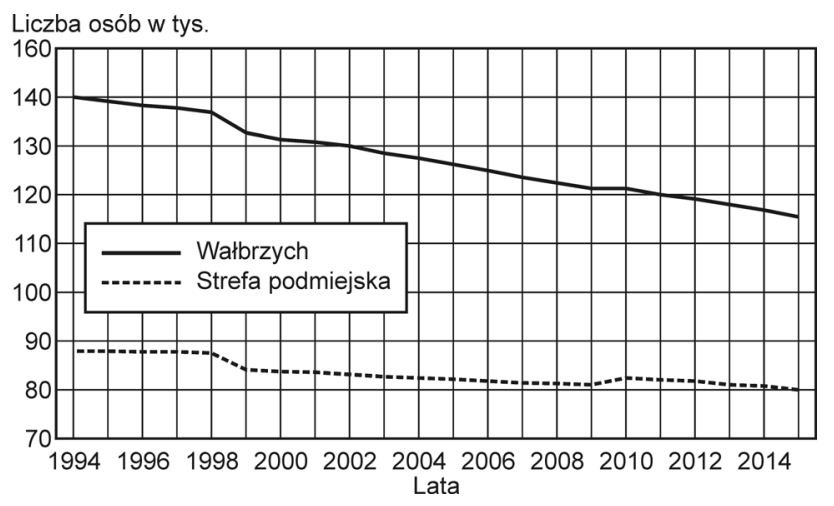

Rys. 4. Liczba ludności aglomeracji wałbrzyskiej w latach 1994-2015

Warto zwrócić uwagę na wahania tempa zmian ludnościowych $\mathrm{w}$ niektórych latach omawianego in- terwału (rys. 4). Na przykład w roku 1999 liczba ludności gwałtownie spadła - w Wałbrzychu o około 4 tys. osób, zaś w jego strefie podmiejskiej o blisko 3 tys. Sytuację tę można wyjaśnić korektą liczby ludności w latach okołospisowych; w tym przypadku był to Narodowy Spis Powszechny (NSP) z 2002 r. Podobnie było w roku 2009, kiedy prawdopodobnie także wystąpił spadek wskutek korekty liczby ludności związanej z NSP 2011 r.

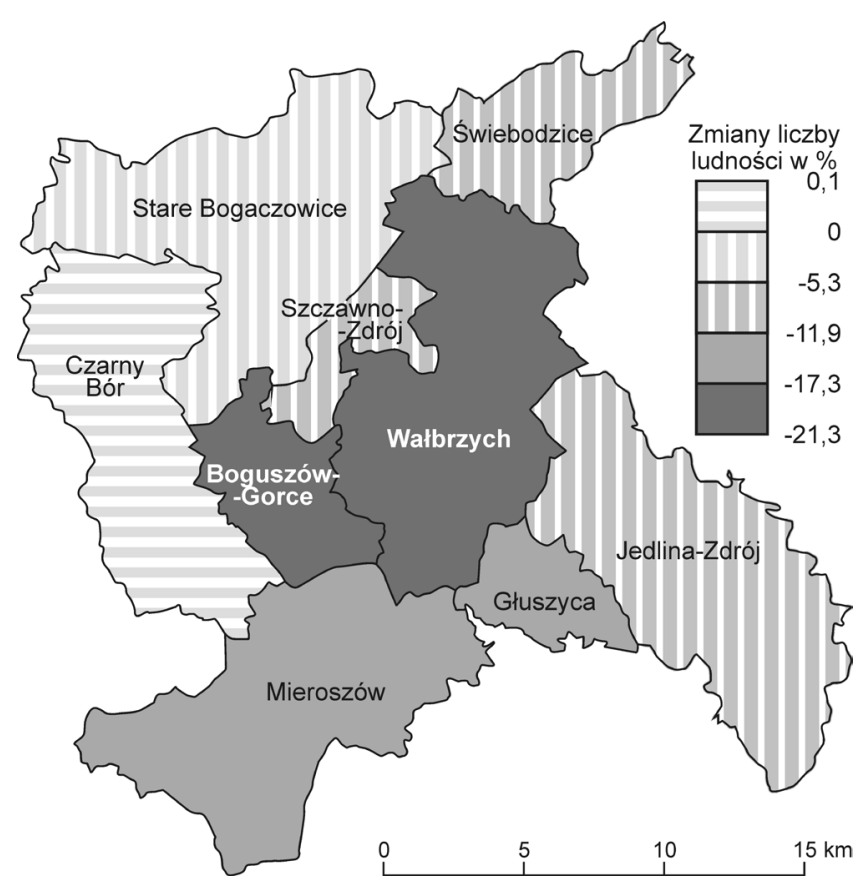

Rys. 5. Zmiany liczby ludności w poszczególnych gminach aglomeracji wałbrzyskiej w latach 1994-2015

Skala depopulacji jest bardzo zróżnicowana przestrzennie wewnątrz aglomeracji (rys. 5). Największe względne ubytki ludności zaobserwowano w miejskich gminach Wałbrzych (o -21,3\%) i Boguszów-Gorce (o -17,3\%), wykazujące największe bezwzględne i względne ubytki (Szmytkie 2015). Liczba ludności znacznie zmniejszyła się także w trzech innych miastach: w Mieroszowie (o -15,5\%), Głuszycy (o -12,7\%) oraz w Jedlinie-Zdroju (o -11,9\%). Najmniejsze zmiany liczby ludności odnotowano zaś w gminach wiejskich: Stare Bogaczowice (o -1,3\%) i Czarny Bór, gdzie liczba ludności $\mathrm{w}$ analizowanym przedziale czasowym nawet wzrosła - o 0,1\%.

Bezpośrednim skutkiem depopulacji omawianej aglomeracji jest zmiana jej struktury demograficznej. W celu dokonania pełniejszej analizy zmian, jakie zaszły w obrębie poszczególnych grup wieku ludności na obszarze Aglomeracji Wałbrzyskiej wykonano wykresy piramidy wieku i płci ludności Wałbrzycha i jego 

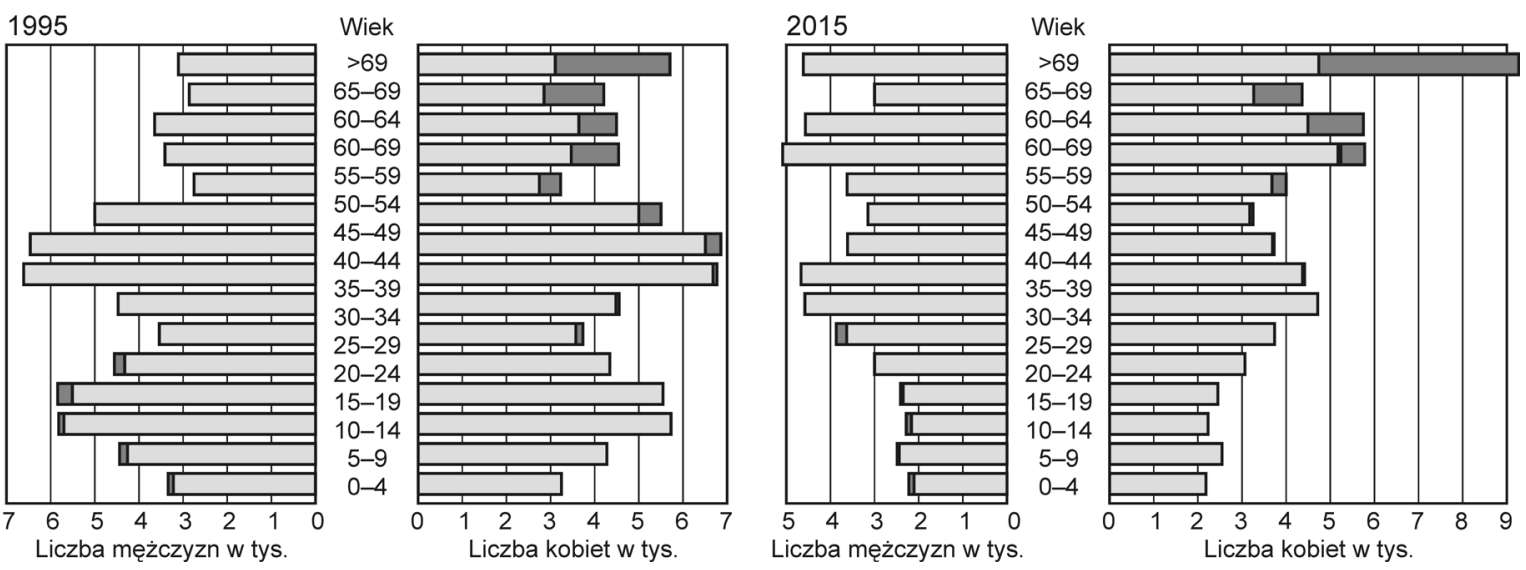

Rys. 6. Struktura wieku i płci ludności w Wałbrzychu w roku: A) 1995 i B) 2015
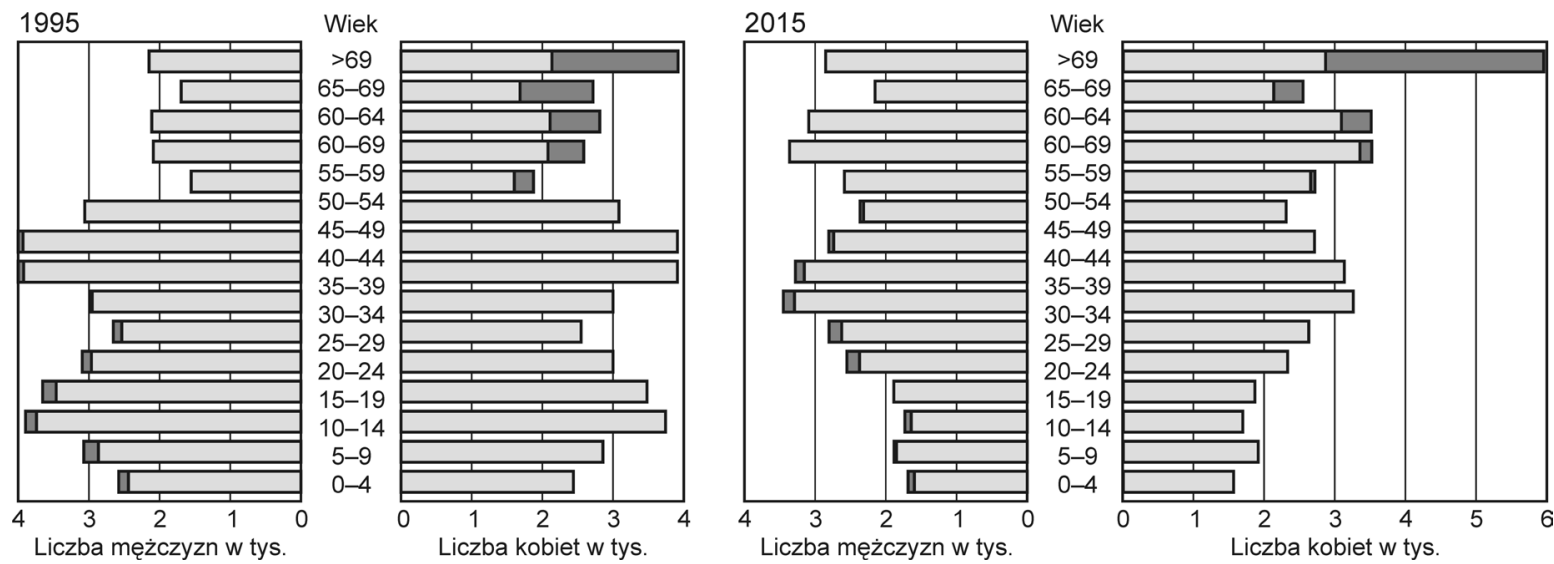

Rys. 7. Struktura wieku i płci ludności w strefie podmiejskiej Wałbrzycha w latach: A) 1995 i B) 2015

strefy podmiejskiej według danych z lat: 1995 i 2015 - rys. 6A-B i rys. 7A-B. Ukazano więc zmiany, w populacji Wałbrzycha i jego strefie podmiejskiej na początku i końcu omawianego okresu.

Struktura ludności według wieku i płci w $1995 \mathrm{r}$. dla Wałbrzycha (rys. 6A) wskazuje, że największą liczbę stanowili wówczas mieszkańcy w wieku 35-44 lat, czyli pochodzący z roczników wyżu kompensacyjnego po II wojnie światowej. Dużą liczebnością wykazały się również grupy wiekowe ludności w wieku przedprodukcyjnym bądź dopiero wchodzące na rynek pracy (10-19 lat). Warto zwrócić uwagę na spadek liczebności roczników młodszych. W przypadku osób w wieku do 24 lat widoczna była w mieście nadwyżka mężczyzn nad kobietami, podczas gdy w starszych rocznikach coraz większa przewaga liczebna kobiet. U kobiet powyżej 70. roku życia była ona niemal dwukrotna. Z porównania rys. $6 \mathrm{~A}$ i $6 \mathrm{~B}$ wynika, że w ciągu 20 lat spadała drastycznie liczba urodzeń, co uwidacznia się w spadku liczebności grup w wieku 0-4 i 5-9 lat.
W tym samym czasie wzrosła liczba osób w wieku ponad 70 lat, co świadczy o procesie starzenia się demograficznego. Na podstawie obu wykresów można stwierdzić, że piramidy wieku i płci dla Wałbrzycha miały postać regresywną dla obu lat badanego okresu.

Największe zmiany, jakie zaszły $\mathrm{w}$ omawianym czasie w strefie podmiejskiej Wałbrzycha nie różnią się zbytnio pod względem trajektorii procesów w stosunku do piramidy wieku i płci Wałbrzycha. Podobnie jak w mieście obserwuje się tu wzrost liczebności roczników poprodukcyjnych oraz spadek liczby ludności w wieku przedprodukcyjnym. Struktura ludności według wieku i płci na obszarze strefy podmiejskiej wykazuje stabilniejszą sytuację niż w Wałbrzychu, co jest widoczne w liczebności poszczególnych grup wiekowych w 1995 i 2015 r. W gminach aglomeracji obserwuje się nadwyżkę liczby mężczyzn nad liczbą kobiet do wieku 44 lat w 1995 r. i 49 lat w 2015 r. W ciagu 20 lat różnica $\mathrm{w}$ starszych grupach wiekowych między liczebnością kobiet i mężczyzn zmniejszała się. 
Konsekwencją spadku liczby ludności są negatywne zmiany w strukturze ekonomicznej ludności. Na szczególną uwagę zasługuje tu proces demograficznego starzenia się społeczeństwa wynikający z koincydencji dwóch niezależnych procesów społecznych. Wzrastający udział liczby ludności w wieku poprodukcyjnym jest konsekwencją zmniejszającej się liczby urodzeń oraz postępującego wzrostu przeciętnego dalszego trwania życia. Inną przyczyną jest relatywny odpływ migracyjny. Częściej bowiem wyjeżdżają ludzie młodzi niż osoby w podeszłym wieku. Inną przyczyną starzenia się społeczeństwa jest również „przesuwanie się" przez kolejne grupy wiekowe roczników demograficznych wyżów i niżów (Holzer 2003).

Starzenie demograficzne ma miejsce również $\mathrm{w}$ aglomeracji wałbrzyskiej (rys. 8), przy czym od $1994 \mathrm{r}$. proces ten szybko postępuje. W 1994 r. ludność w wieku poprodukcyjnym stanowiła 14,1\% ludności Wałbrzycha i 14,5\% mieszkańców jego strefy podmiejskiej. $\mathrm{W}$ ciągu 20 lat udziały te drastycznie wzrosły i obecnie (2015 r.) blisko $1 / 4$ wałbrzyszan $(23,6 \%)$ jest $\mathrm{w}$ wieku poprodukcyjnym, a w strefie podmiejskiej $21,2 \%$.

Warto zwrócić uwagę, że proces ten nie zachodził równomiernie przez cały ten okres, gdyż wyraźnie zwolnił w latach 2000-2005, po czym ponownie przyspieszył po 2010 r. Odtąd wartość przyrostu odsetka ludności w wieku poprodukcyjnym co roku zwiększa się o około 0,9\%. Prawdopodobnie był to wynik emigracji ludzi młodych na Zachód, co na większą skalę stało się możliwe po otwarciu dla Polaków rynków pracy państw Unii Europejskiej, które nastąpiło po wejściu Polski do UE w 2004 r. Wyraźna jest tendencja wzrostu udziału ludności w wieku emerytalnym w strukturze badanej populacji.

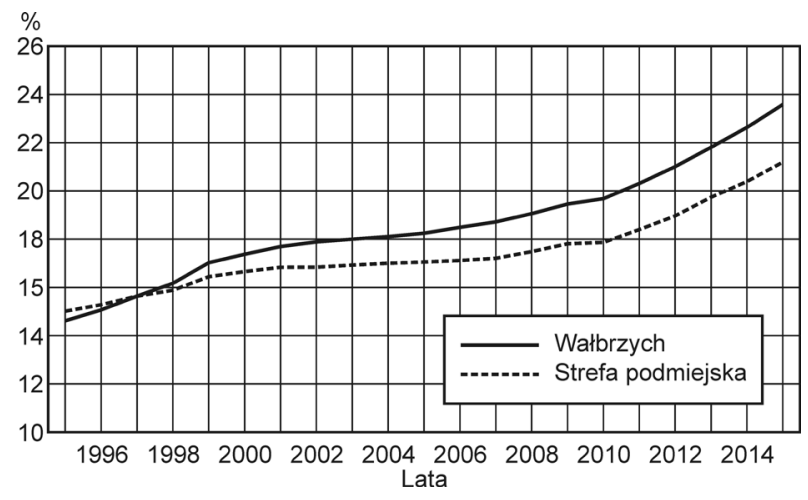

Rys. 8. Wzrost odsetka ludności w wieku poprodukcyjnym w strukturze populacji aglomeracji wałbrzyskiej w latach 1995-2015

O starzeniu demograficznym dobrze informuje indeks starości, czyli stosunek liczby ludności w wieku poprodukcyjnym do ludności w wieku przedprodukcyjnym (rys. 9). Zależny jest od dwóch czynników natury demograficznej; może bowiem się zwiększać wskutek zmniejszającej się liczby urodzeń i w efekcie przyrostu liczby ludności w wieku poprodukcyjnym. Indeks starości dla aglomeracji wałbrzyskiej wzrósł znacznie - od 55,7 w Wałbrzychu i 58,9 w jego strefie podmiejskiej w 1995 r. do 162,3 w mieście i 132,4 w tej strefie w roku 2015, czyli odpowiednio 2,9-krotnie i 2,2-krotnie. Oznacza to taki właśnie liczebny przyrost osób starszych na analizowanym obszarze.

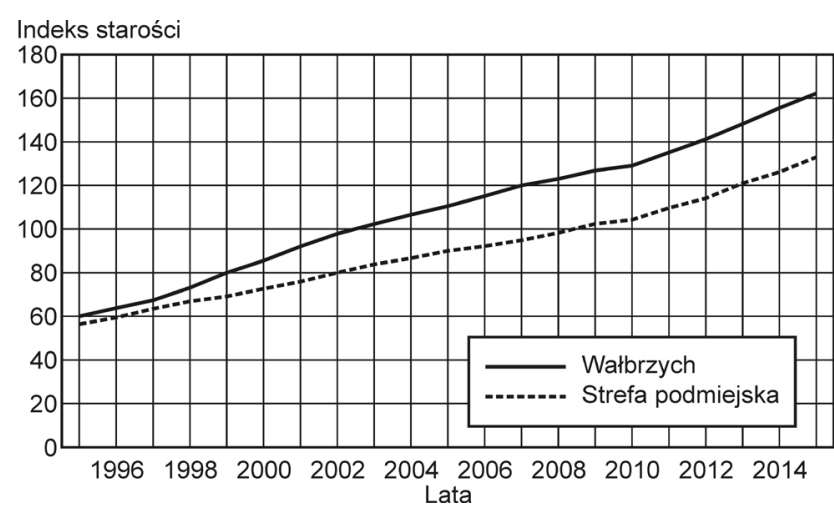

Rys. 9. Wzrost indeksu starości w aglomeracji wałbrzyskiej w latach 1994-2015

Tak gwałtowne starzenie się demograficzne implikuje konieczność podjęcia określonej polityki, uwzględniającej konieczność dostosowania różnych sfer życia społeczno-ekonomicznego do obsługi osób w starszym wieku. Problem ten wymaga natychmiastowych rozwiązań.

\section{PODSUMOWANIE}

Depopulacja na obszarze aglomeracji wałbrzyskiej nastąpiła na skutek gospodarczej stagnacji, utrzymującej się od początku transformacji funkcjonalnej i upadku wielu gałęzi przemysłu. Zaistniałe na skutek tych przemian demograficzne zmiany odzwierciedlają tempo depopulacji. Na wyludnianie się tej aglomeracji niemal równomiernie wpływają: ubytek naturalny (będący konsekwencją spadku przyrostu naturalnego spowodowanego niskim współczynnikiem urodzeń) oraz odpływ migracyjny, który dotyczy przede wszystkim młodych osób. Spośród gmin leżących w aglomeracji wałbrzyskiej najszybciej wyludniają się miasta: Wałbrzych i Boguszów-Gorce, gdzie liczba mieszkańców w okresie 1994-2015 r. zmniejszyła się odpowiednio 
o $21,3 \%$ i $17,3 \%$. Najmniejsze zmiany zaszły w gminach wiejskich Czarny Bór i Stare Bogaczowice, na terenie których zachodzą procesy suburbanizacji (por. Szmytkie 2016).

Problem depopulacji aglomeracji wałbrzyskiej będzie coraz poważniejszy, o czym świadczą tendencje do ujemnych wartości współczynnika ubytku naturalnego oraz ujemnego salda migracji. Na skutek tych obu przemian liczba osób w wieku poprodukcyjnym będzie się szybko powiększać, przede wszystkim przez wejście osób pochodzących z powojennego wyżu demograficznego, ale także dalszego spadku liczby urodzeń. W efekcie na obszarze Wałbrzycha i jego strefy podmiejskiej nastąpi przyspieszenie procesu starzenia demograficznego.

\section{BIBLIOGRAFIA}

Ciok S., Dołzbłasz S., Raczyk A., 2006, Dolny Śląsk: problemy rozwoju regionalnego, „Studia Geograficzne”, 79.

Dołzbłasz S., Mucha P., 2015, Wykorzystanie terenów pogórniczych na przykładzie Wałbrzycha, „Studia Miejskie”, 17, s. 109-121.

Holzer J., 2003, Demografia, Polskie Wydawnictwo Ekonomiczne, Warszawa.

Jaroszewska E., 2014, Wałbrzych - dziedzictwo przeszłości a wyzwania przyszłości, [w:] T. Stryjakiewicz (red.), Procesy kurczenia się miast Europy Środkowo-Wschodniej, Bogucki Wyd. Naukowe, Poznań, s. 102-114.

Kantor-Pietraga I., 2014, Systematyka procesu depopulacji miast na obszarze Polski od XIX do XXI wieku, Wyd. Uniwersytetu Śląskiego, Katowice.
Kantor-Pietraga I., Krzysztofik R., Runge J., 2012, Kontekst geograficzny i funkcjonalny kurczenia się małych miast w Polsce pohudniowej, [w:] K. Heffner, A. Halama (red.), Ewolucja funkcji małych miast w Polsce, „Studia Ekonomiczne. Zeszyty Naukowe Wydziałowe Uniwersytetu Ekonomicznego w Katowicach”, 92, s. 9-24.

Kosmaty J., 2011, Wałbrzyskie tereny pogórnicze po 15 latach od zakończenia eksploatacji węgla, „Górnictwo i Geologia”, 6, 1, s. 131-148.

Maik W., 1992, Podstawy geografii miast, Wyd. Uniwersytetu Mikołaja Kopernika w Toruniu, Torun.

Parysek J.J., 2005, Miasta polskie na przełomie XX i XXI wieku. Rozwój i przekształcenia strukturalne, Bogucki Wyd. Naukowe, Poznań.

Rocznik statystyczny województwa wałbrzyskiego 1994, 1995, Wojewódzki Urząd Statystyczny w Wałbrzychu, Wałbrzych.

Szmytkie R., 2015, Zjawisko kurczenia się miast bardzo małych w Polsce, [w:] A. Wolaniuk (red.), Wspótczesne czynniki i bariery rozwoju miast, „Konwersatorium Wiedzy o Mieście”, 28, Wyd. Uniwersytetu Łódzkiego, Łódź, s. 259-276.

Szmytkie R., 2016, Depopulacja zespołów miejskich w sudeckiej części Dolnego Śląska, [w:] A. Wolaniuk (red.), Rozwój lokalnych i regionalnych systemów osadniczych $w X X I$ wieku, ,Konwersatorium Wiedzy o Mieście", 29, Wyd. Uniwersytetu Łódzkiego, Łódź. s. 75-83.

Szymańska D., 2009, Geografia osadnictwa, Wyd. Naukowe PWN, Warszawa.

Wójcik J., 2011, Przemiany wybranych komponentów środowiska przyrodniczego rejonu wałbrzyskiego w latach 1975-2000, w warunkach antropopresji, ze szczególnym uwzględnieniem wpływu przemyshu, „Rozprawy Naukowe Instytutu Geografii i Rozwoju Regionalnego”, Uniwersytet Wrocławski, Wrocław.

Zborowski A., Soja M. Łobodzińska A., 2012, Population trends in Polish cities - stagnation, depopulation or shrinkage?, „Prace Geograficzne IGiGP Uniwersytetu Jagiellońskiego”, 130, s. 7-28.

https://bdl.stat.gov.pl/BDL/start; 23.05.2017.

Artykuł wpłyną: 27 maja 2017 Zaakceptowano do druku: 12 października 2017 